\title{
Brug af podcasts $i$ undervisningen \\ - muligheder og begrænsninger
}

\section{Helle Mathiasen}

\section{Professor}

Institut for Informations- og Medievidenskab, Aarhus Universitet

\section{Abstract}

Med udgangspunkt i et konkret undervisningsforløb, hvor podcast, har været en del af det samlede undervisningsmateriale, redegøres først for forløbets samlede rammesætning og derefter redegøres for artiklens empiriske afsæt. Pod er et akronym for programmes-on-demand og cast henviser til begrebet broadcast. I nærværende artikel defineres podcast som et medie, der er præsenteret ved lyd og/eller video, og et medie der kan tilgås, når det ønskes, ifald bruger har mulighed for at bruge fx en computer, ipod eller en mp3.

Den empiriske undersøgelse inkluderer, udover brugen af podcasts, lurking $1 \mathrm{i}$ konferencesystem og de studerendes weblogs, observationer af undervisning, interview med studerende samt interview med semesterkursets tilrettelægger og underviser.

${ }^{1}$ At kigge med uden at bidrage. 
Ud fra en kommunikations- og læringsteoretisk ramme udfoldes

podcastmediets potentialer og begrænsninger og artiklen afsluttes med en invitation til fortsat diskussion af podcastmediet fremtid i uddannelsessystemet.

\section{Indledning}

Artiklen tager afsæt i et casestudie af studerendes brug af podcasts i forbindelse med et konkret undervisningsforløb. Omdrejningspunktet er didaktiske perspektiver i forbindelse med brug af podcast $\mathrm{i}$ undervisningen. De i øvrigt yderst relevante juridiske og økonomiske aspekter i forbindelse med inddragelse af podcasts i undervisningen er ikke tema for diskussion i denne artikel.

Udgangspunktet for den didaktiske diskussion er en kommunikations- og læringsteoretisk optik på inddragelse af forskellige kategorier af podcasts i undervisningen. I denne diskussion inddrages den casebaserede empiriske undersøgelse som et konkret eksempel på studerendes tilgang til og refleksioner over et specifikt tilrettelagt undervisningsforløb, et semester på seks måneder.

Podcast vil blive defineret inden for den anlagte systemteoretiske ramme som et udbredelsesmedie. I tidsskriftnummerets indledende artikel introduceres begrebet vidensmedier i en sociokulturel optik, hvor medier ikke forstås som medier (for viden) i sig selv, men som tilbud til egen videnskonstruktion, som fx når den studerende tager et vidensmedie i brug med det formål at konstruere viden.

I den systemteoretiske optik betyder det, at mediet tilbyder formidling af information og at denne information er meddelers valg. Et vidensmedie kan siges at tilbyde udbredelse af viden i den forstand, at viden er systemspecifik og dermed systemrelateret - her konkret meddelerrelateret.

Det betyder ikke, at fx den studerende, der bruger et vidensmedie, danner samme videnskonstruktion, som mediet tilbyder. Den studerende bygger sine systemspecifikke videnskonstruktioner, som ikke nødvendigvis, måske sjældent er ækvivalerende med den af meddeler formidlede videnskonstruktion. Dette udfoldes i afsnittet om det kommunikations- og læringsteoretiske afsæt.

Vidensbegrebet er rammesat som personafhængigt - i systemteoretiske begreber mere generelt som systemafhængigt. Begrebet vidensmedier kan således ikke forstås som medier, der tilbyder at kunne transformere denne viden til kendt såvel som ukendt adressat, eksempelvis de studerende. Den viden, som et medie tilbyder som information til adressat, er derfor ikke udtryk for universelle sandheder, men i princippet udtryk for én 
konstruktion, relateret til et konkret system, fx til underviser. Det teoretiske afsnit vil udfolde denne pointe ud fra en systemteoretisk optik og med fokus på kommunikation og videnskonstruktion.

Kommunikations- og læringsteoretisk kan podcast tillægges et læringspotentiale. Med inspiration fra casestudiet udfoldes dette aspekt ved bl.a. at fokusere på konkrete anvendelseskontekster. Forskningen peger på, at teknologien tilbyder en vifte af funktioner, men at denne vifte af muligheder ofte ikke bruges i større omfang af underviser og studerende (Cuban, 1986). I den sammenhæng skal nævnes Bo Fibigers fremlæggelse af "state of the art" inden for de senere års digitale medieforskning $\mathrm{i}$ nærværende tidsskriftnummer.

Flere studerende vælger teknologien fra i undervisningsrelaterede sammenhænge trods en undervisningstilrettelæggelse, der inviterer til en sådan bred og varieret brug af den til rådighed værende teknologi (Dalsgaard \& Mathiasen, 2006, Mathiasen, 2002, 2004, 2006, 2007).

Fx viser det inkluderede casestudie, at flere studerende ofte vælger den i teorien læringsunderstøttende mulighed fra, selvom det aktuelle undervisningsforløb, hvor didaktiske argumenter for aktualisering af bl.a. podcast er blevet ekspliciteret og hvor undervisningen er baseret på studerendes aktive inddragelse af de tilbudte medier. I afsnittet om casestudiet vil de studerendes argumenter for fravalg af til rådighed stående medier, med fokus på podcats blive udfoldet.

\section{Undersøgelsesdesign}

Den empiriske undersøgelse, hvis fokus er studerendes brug af podcast i en konkret undervisningsforløb, inkluderer lurking i konferencesystem og de studerendes weblogs med fokus på temaer aktualiseret af podcasts, observationer af tilstedeværelsesbaseret undervisning, interview med de studerende samt interview med kursets tilrettelægger og underviser. Observationer er udført i slutningen af forløbet og i forbindelse med inddragelse af en podcast i kategori 3 (talking head) i den tilstedeværelsesbaserede undervisning. Alle studerende på overbygningsfaget betragtes som informanter, hvad angår informationsindsamling i forbindelse med observation og lurking.

Interviews af studerende er dels gennemført i slutningen af undervisningsforløbet (efter observationer) og før aflevering af den skriftlige eksamensopgave og dels efter aflevering af eksamensopgave men før karakterfastsættelse. Interviews har haft en varighed på godt 60 minutter. 
Der er gennemført gruppeinterview og enkeltinterview af studerende, da hvert interviewkoncept har sine fordele og ulemper med hensyn til udfoldelse af temaet. Gruppeinterview kan bl.a. udfolde temaet ud fra de deltagendes forskellige optikker og udsætte udtømning af et tema, mens enkeltinterview bl.a. giver mulighed for udfoldelse af temaet på den enkelte informants præmisser.

Kriterier for valg af informanter til interviewene, afviklet i slutningen af undervisningsforløbet, var det muliges princip, i den forstand, at de studerende på holdet blev spurgt om de kunne afsætte tid til et interview. De studerende, der kunne det, blev interviewet. I gruppeinterview, afviklet efter aflevering af eksamensopgave, deltog en repræsentant for hver af de fem arbejdsgrupper, der var blevet dannet i løbet af undervisningsforløbet. Baggrunden for dette udvælgelseskriterium var, at så mange forskellige tilgange som muligt skulle bringes i spil. Det samlede antal af inddragne informanter udgør knap $75 \%$ af holdet.

Efter eksamen og dermed karakterfastsættelse af de indleverede skriftlige eksamensopgaver er underviser blevet interviewet og med en mailkorrespondance som opfølgning på interviewet.

De gennemgående interviewspørgsmål til de studerende var følgende: Hvilke undervisningsmedier ${ }^{2}$ har I/du brugt på kurset (fx trykt litteratur, netmedierede txt'er, video, konferenceplatforme, Podcast, forskellige kategorier? Hvordan og hvor har I/du brugt de forskellige undervisningsmedier? Hvilke undervisningsmedier foretrækker I/du? Hvordan oplever I/du, at de forskellige medier spiller sammen i forhold til at understøtte jeres/dine lærerprocesser? Hvordan bruges de forskellige medier af underviser i selve undervisningen? Er der nogle kommunikationsfora I/du foretrækker? Og hvorfor? Og hvornår? Har I/du nogle råd til kommende kurser, hvor netmedier kan bruges i kombination med mere traditionelle undervisningsmedier som bogen og netmedierede tekster?

Interviewspørgsmålene til underviser var følgende: Hvordan er medierne tænkt ind i undervisningsforløbet? Hvordan er de blevet brugt af hhv. underviser og studerende? Er der forskel på kommunikationen alt efter brug af medier? Er der en mere frugtbar (faglig) kommunikation i undervisningen, når de studerende har brugt podcast? Er podcast noget du vil fortsætte med at bruge og evt. selv fortsætte med at producere? Hvorfor?, hvordan?, i hvilke sammenhænge?, med hvilke formål?

${ }^{2}$ Som synonym for begreberne udbredelsesmedier, vidensmedier (kernebegreb i antologien) og ressource bruges begrebet undervisningsmedier, i forbindelse med interview af studerende. 


\section{Et casestudie}

\subsection{Rammer for undervisningen}

Forskningsprojektets genstandsfelt er et kandidatoverbygningsfag, afviklet over et efterårssemester. Undervisningen blev organiseret som ugentlige underviserorganiserede oplæg af tre lektioners varighed. Med underviserorganiseret skal her forstås, at underviser har tilrettelagt undervisningens overordnede rammer. De enkelte undervisningsgange har taget udgangspunkt i spørgsmål til tekster/podcasts, stillet af de studerende forud for selve undervisningen på universitetet.

Undervisningen har af underviser i væsentlig grad haft faglige diskussioner som omdrejningspunkt.

I undervisningsforløbet har der været indlagt tre opgaver, som de studerende (gruppevis) skulle arbejde med mellem de enkelte undervisningsgange og efterfølgende fremlægge og diskutere i plenum.

Udover ovenstående tilstedeværelseskommunikationsforum er overbygningsfaget tilrettelagt som en kombination af forskellige netmedierede kommunikationsfora. De studerende skulle oprette en weblog, som skulle bruges til at stille spørgsmål til fagets tekster, til at give udtryk for refleksioner over de anviste tekster i kursusplanen samt invitere til diskussion om fagets aktualiserede temaer.

Universitetets konferencesystem havde primært funktion af informationsdistribution som $\mathrm{fx}$ formalia om kurset, kursusplan, links til relevante tekster, tekstdokumenter, pp-præsentationer og forskellige kategorier af podcasts. Yderligere var mail-kommunikation en del af det samlede kommunikationsrepertoire.

Overbygningsfagets formål var at få de studerende til på en bred læringsog kommunikationsteoretisk baggrund at kunne skitsere og argumentere for, hvordan digitale medier udvikles og tilrettelægges, således at disse vil kunne understøtte kommunikation, læring og samarbejde.

Casestudiet har primært fokuseret på de studerendes brug af de til faget tilbudte podcast.

Underviser har valgt at inkludere tre forskellige kategorier af podcast ${ }^{3}$. Den første kategori er ca. 5 minutters præsentationer (instruktioner) inkluderende PowerPoint-præsentationer, den anden kategori (består af tre filer: 2.1., 2.2. og 2.3) er ca. 7 minutters demonstrationer, inkluderende videosekvenser. Den tredje kategori er videooptagelse af en forelæsning på

\footnotetext{
3 Se særskilte pdf filer med videomaterialer.
} 
ca. 45 minutter, hvor forelæser er filmet i forgrund og med forelæsers PowerPoint som oplyst baggrund for "the talking head".

Ud over de nævnte podcast, i alt 11 tilbudte podcast, fordelt på 2 produktioner af første kategori, 7

produktioner af anden kategori og 2 produktioner af tredje kategori var litteratur til faget i form af et kompendium, en grundbog samt diverse links meddelt via konferencesystemets postsystem. Den angivne litteratur samt de nævnte podcast forventes, af underviser, anvendt af de studerende.

De studerende blev opfordret af underviser til at stille spørgsmål til de aktuelle forelæsningstekster og podcast via deres private weblog. Underviser tog så disse spørgsmål op i forelæsningen, og valgte dermed, at tage de temaer op, som de studerende havde valgt at spørge til i de medier, der var aktuelle for den specifikke forelæsning. Underviser opfordrede de studerende til at arbejde sammen om opgaver og forberedelse til de enkelte forelæsninger.

\subsection{Rammesætning, - undervisers intentioner og refleksioner}

For at få et billede af den samlede undervisningsmæssige ramme vil den undervisningsorganisatoriske ramme, hvori podcasts er inkluderet kort blive ridset op.

Når det drejer sig om konkret brug af de forskellige netmedierede kommunikationsfora, var undervisers intention, at de studerende skulle læse de angivne tekster til hver undervisningsgang (kursusplan lagt i konferencesystemet) og derefter producere spørgsmål til underviser om teksterne på deres weblog. De studerendes egne weblogs var tiltænkt en central rolle i forbindelse med forberedelser til tilstedeværelsesundervisningen.

Den grundlæggende ide fra undervisers side har været, at undervisningsforløbet skulle være "problemorienteret og orienteret mod praksis". De studerende forventes selvstændigt (egenstyring) at kunne aktualisere de tilbudte ressourcer (weblogs, podcast, kompendium osv.), da intentionen er, at de studerendes aktiviteter blev båret af selvgenereret målrettethed og egne refleksioner over aktiviteterne og den konkrete brug af de tilbudte medier. Som en konsekvens af denne tilgang til de studerendes videnskonstruktionsprocesser har underviser valgt specifikke roller til sig selv:

\footnotetext{
"Jeg forsøgte at indtage en rolle som koordinator/tilrettelægger i den forstand, at jeg har lavet en struktur på kurset og ikke
} 
mindst, at jeg har stillet en række spørgsmål og problemstillinger, der skulle behandles. Derudover har jeg betragtet mig selv som "hjælper" og spørgsmålsbesvarer. Dvs. i modsætning til formidler. Jeg har stillet dem spørgsmål og har medvirket i diskussion af spørgsmålene - og har besvaret/diskuteret de spørgsmål, de har stillet."

Undervisers forventninger til de studerendes roller:

"De studerendes rolle har været at arbejde selvstændigt (evt. i grupper) med en problemstilling. Forholdsvis tidligt i forløbet skulle de studerende finde en problemstilling. Derudover har de skullet diskutere spørgsmålene, der blev stillet. [...] Det centrale er, at de studerende skal være aktive og selvstændige - at de skal behandle og anvende de forskellige ressourcer, de har stillet til rådighed."

Underviser benævner de valgte medier som ressourcer, heri ligger der en toning mod at disse anses for tilbud til den studerende. Undervisers intention er at de studerende selv aktivt vælger de ressourcer, de studerende forventer, vil kunne understøtte deres læreprocesser. Ideen om at de studerende er aktive studerende, som vil studiet/faget og derfor bruger den nødvendige tid til at sætte sig ind i studiets anlagte temaer, forholde sig til de angivne ressourcer (grundbog, kompendium, links, weblogs, konferencesystem og podcast-produktionerne) er således den bærende tilgang til undervisningsforløbet.

Ifølge underviser kan de forskellige ressourcer volumenmæssigt rangordnes, således at tyngden har

"ligget på de trykte tekster, nr. 1, links nr. 2, nr.3 er weblogs. Podcast/videoerne fyldte også i de perioder de blev brugt".

Underviser tillægger således selv udbredelsesmedier i form af trykte tekster en væsentlig rolle, hvilket afspejles i litteraturlisten til faget.

"De små videoer fyldte mest i løbet af 2 uger, jeg ved ikke om de er blevet brugt senere. De skulle ses som en palet og så kunne de dykke ned i det, introduktion, så kunne de selv gå i dybden. Videoerne var ressourcer." 
Med hensyn til de studerendes forskellige tilgange til brugen af de tilbudte netmedierede kommunikationsfora og ressourcer nævner underviser at:

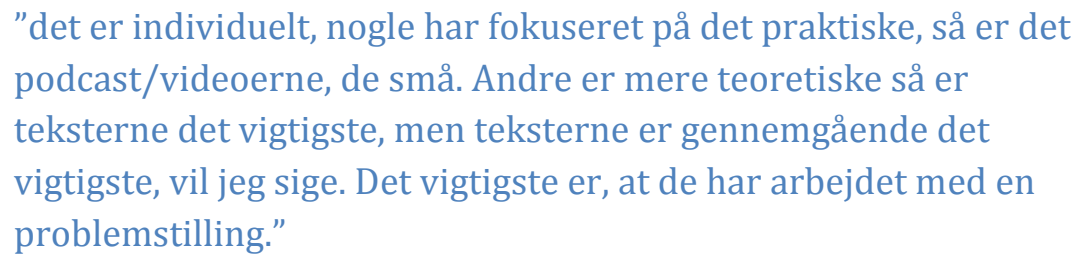

Underviser tillægger podcast/videoerne en læringsmæssig betydning mere for nogle studerende end andre - og pointerer samtidig, at de tekstbårne medier, som bog, kompendium og tekster/links på nettet har den største tyngde i forhold til fagets mål og indhold. Samtidig ser underviser en mere målrettet brug af podcasts ved at inddrage disse i undervisningen i fx form af konkrete opgaver i tilknytning til disse:

"de korte videoer ved jeg ikke, jeg tror måske de har set dem, og
tænkt nå ja, nu ved jeg hvad det er, har en ide om hvad det er, en
passiv anvendelse, der skulle jeg have givet dem nogle opgaver.
De lange videoer har de ikke brugt, tror jeg."

Når de "lange videoer" (kategori 3, talking head) ikke, ifølge undervisers opfattelse, aktualiseres af de studerende, er det nærliggende at spørge til formålet med disse i forhold til undervisningsforløbet og den konkrete undervisning.

På spørgsmålet om brugen af podcasts/videoer har betydning for kommunikationen, og dermed for en frugtbar og udfoldet diskussion i den tilstedeværelsesbaserede undervisning, svarer underviser:
"det giver nogle forskellige fokuspunkter og koblinger...man kan sige det giver en anden indgang, noget man også kunne gøre, ...kig på videoen og lav selv...folk kan komme med forskellige erfaringer... jeg har ikke tænkt så meget over lige det."

Underviser skelner mellem "korte" (kategori 1 og 2) og "lange" (kategori 3) podcasts og deres primære formål, hvilket betyder, at de "korte" er tænkt som medier, der kan informere og inspirere til egne aktiviteter evt. de studerendes egne podcast-produktioner, mens de "lange" podcasts er tænkt som supplerende materiale som forberedelse til en undervisningsgang.

Podcast-kategori 3 (talking head) opfattes af underviser som en form for tekst. 
"jeg vælger at se dem, som læsepensum, som ressourcer, det er selvfølgelig nemt at sige, at alt er ressourcer, forelæsninger, videoklip, tekster... men jeg sidestiller lidt en forelæsning med en tekst"

Underviser udelukker ikke ny egenproduktion af "korte" podcasts:

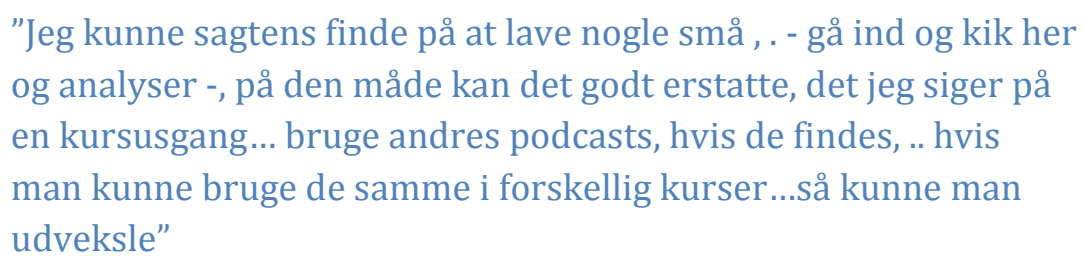

Ideen om medier som fx podcasts kan fremstå som en kontekstfrit og genbrugelige i andre kontekster, kræver bl.a. at der ikke er udspændt et net af referencer til andre læringsressourcer og at faktuel viden må kunne stå alene. Den erfaring kommer til udtryk ved, at underviser må korrigere i egne podcast-produktioner. "Jeg måtte slette henvisninger fra en video til en anden.".

Som konkrete eksempler på podcasts/videoer, der kunne være nyttige som ressource foreslår underviser en form for dokumentar af en konkret specifik praksis:

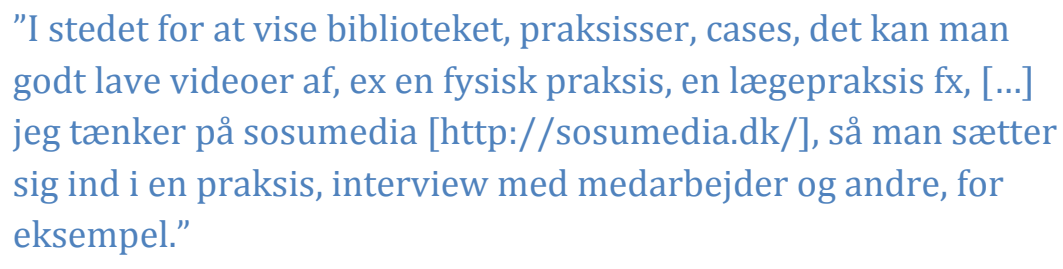

Underviser ser efter det konkrete forløb stadig undervisnings- og læringsmæssige potentialer i podcastmediet. I det følgende vendes blikket mod de studerende og deres tilgang til brugen af podcasts i undervisningen.

\subsection{De studerendes tilgang og refleksioner}

I dette afsnit vil samtlige interviewtekster blive inddraget ${ }^{4}$. Analysen er opdelt i følgende temaer:

Podcasts, form og indhold, Podcasts, fleksibilitet, tid og sted, Podcasts, kommunikation og læring, podcasts og det sociale, samt Podcasts og undervisning. Først et afsnit, der fokuserer på podcastmedier.

${ }^{4}$ Da gruppeinterview afviklet efter aflevering af eksamensopgave indholdsmæssigt ikke adskiller sig fra interview foretaget før eksamensopgaveaflevering, er alle interview anvendt under samtlige temaer. 


\title{
Podcasts
}

De fleste studerende er enige om, at de korte podcasts har en fremtid inden for uddannelsessystemet.

\author{
"Det var egentlig en god måde at præsentere fx \\ konferencesystemers og netleksikas funktionaliteter, så tog det \\ ikke tid fra forelæsningerne og det gjorde det samtidig lettere at \\ forstå, så man selv lettere kunne gøre det bagefter"
}

Det kræver dog bedre kvalitet, klare mål for den enkelte podcast, som en student fremfører:"hvorfor skal vi bruge tid på denne podcast?". Yderligere kræver det, at podcasts bliver integreret i undervisningen, dvs. bliver tematiseret i den tilstedeværelsesbaserede undervisningen. Når det drejer sig om "Talking head" (3. kategori) er de studerende stort set enige om den begrænsede nytte i den nuværende udformning af disse længerevarende (ca. 45 minutter) videoer.

En studerende fortæller:

"Jeg forstår ikke, det giver overhovedet ingen mening at sætte et
kamera op ved siden af et slideshow, INGEN mening [...] . Man
kan jo ikke sige at videomediet er noget nyt, [...] men det bliver
på mediet præmisser. Jeg tror ikke på det der med, at nu
podcaster vi alt, altså ud på universitetets hjemmeside osv. Det
tror jeg ikke på. Tiden er måske løbet fra forelæsningsformen, og
det bliver bare så tydeligt, når det bliver på til video. Altså alle de
små sociale ting er skrællet væk. Det groteske bliver udstillet
meget skarpt."

Den studerende sætter fokus på kommunikationen og dennes præmisser, og tematiserer bl.a., hvad "en-vejs-kommunikation" i sin ekstreme version kan tilbyde, og dermed den manglende mulighed for forståelseskontrol og feedback. ${ }^{5}$

Indholdet af følgende udtalelse om podcasts, i form af "Talking head" fra et gruppeinterview kan genfindes i samtlige interviews:

\footnotetext{
"Det med steaming af noget video, altså den form, vi er blevet præsenteret for, skal videreudvikles før det er brugbart. Hvis der kunne skabes mulighed for noter, altså der skal laves et noteapparat, der skal op at køre og køre det sammen med
}

\footnotetext{
5 Inden for kategori 3, "Talking head", findes der mere raffinerede fremtrædelsesformer, hvor fx skærmen er delt op, så adressat både kan iagttage forelæser, slideshow og tilhører i forelæsningslokalet, samt kan deltage enten skriftligt eller mundtlig med feedback i form at spørgsmål eller kommentarer til forelæsningen, - løbende eller efter forelæsningen kommunikation med forelæser og evt. tilhører i forelæsningslokalet.
} 
videoen, og bedre i lyd og billeder og at forelæserne performer lidt bedre, men der er helt klar muligheder i mediet. Kvaliteten skal være bedre... det har meget med den her vedkommenhed at gøre"

De studerende fokuserer dels på mangel på kvalitet, hvad angår lyd og billeder, dels på manglen på aktualisering af supplerende funktioner, eksempelvis fortløbende tekst, links og lignende. "kontekstmarkører" som understøtter forelæsers mundtlige formidling. Endvidere efterlyser de studerende forelæsere, der kan agere i podcast/video-mediet.

Podcasts, form og indhold

Udpluk af dialog mellem to studerende (A og B) i gruppeinterview:

"A: Det visuelle er altid godt, ideen er god nok, men det skal udvikles, der skal være kapitler, altså du skal kunne springe over, og tage det der er relevant for en selv.

B: Jamen lige meget hvad, skal det fremgår, hvor langt det er, ligesom når man har en bog $\mathrm{fx}$

A.:Pods det virker fint med de små sekvenser, det har meget at gøre med længde".

Podcastmediet sammenlignes med kendte medier som bogen, med indholdsfortegnelsens sekventielle angivelse af temaer og disses sideomfang. Den gængse tænkning om referenceangivelse via de trykte medier, fx fremlæggelser, opgaver og til eksamen udfoldes på følgende måde af en studerende:

\footnotetext{
"Det er noget andet med en video af fx hele forelæsninger, altså hvis man nu skal læse en artikel, skal man vide lidt om, hvor lang tid den tager at læse, i hvilken kontekst den er skrevet osv. Det er noget andet med en video, man kan ikke bruge det til at referere til, da talen er anderledes end en tekst- men den kan bruges til at sætte tanker i gang, og som adspredelse."
}

Her fremdrager den studerende det "flygtige" element af mediet med reference til form og organisering, Samtidig gives der udtryk for at mediet kan iagttages, jf. den efterfølgende diskussion, som netop "ikke-flygtig" i den forstand, at mediet tilbyder reintroduktion, i form af iterationer af frem- og tilbagespoling. 
En studerende foreslår at podcasts/videoer bruges som understøttende og udfoldende og på mediets præmisser og ikke tænkes som noget, der skal kunne anvendes på trykte mediers præmisser:

"Jeg kunne forestille mig at man bruger filmmedier på dokumentarismens præmisser. Altså fx at vi har læst en tekst og så kommer underviser og siger, se denne film, den er netop et eksempel på det I har læst som tekst til i dag. Man lærer jo utroligt meget ved at se fjernsyn. Og så kunne vi her supplere med sådanne fim til teorierne, men det er jo et enormt arbejde, og dyrt."

Flere studerede ser podcasts som inspirationsgenererende, men der er et stykke vej endnu, før mediet når kendte mediers form og indholdskvaliteter.

Podcasts, fleksibilitet, tid og sted

De studerende er stort set enige om at de har vanskeligheder ved at koncentrere sig om de tilbudte podcast-produktioner, samtidig med at de foretager sig noget andet. Multi-tasking er ikke noget, der i denne sammenhæng bringes i spil.
"A: Podcast : ikke i bussen, men gerne foran computeren, når jeg kan spole frem og tilbage. $\quad$ B: Nej så vil jeg hellere nyde naturen hvis jeg skal løbe en tur eller cykle...
Det vil være voldsomt for mig ikke at have forelæsninger, men nye studerende vil sikkert kunne det.
C: Hvis det var en podcast-forelæsning, som jeg havde været til, vil jeg kun tage den frem, hvis jeg skulle bruge den eller til eksamen i den. Hvis jeg ikke havde været til forelæsningen ville jeg se den derhjemme foran computere." 6

En enkelt studerende giver et eksempel på en belejlig podcast-anvendelse:

$$
\begin{aligned}
& \text { "...engang imellem skal jeg over til min mor, og efter jeg har fået } \\
& \text { mulighed for at få lyd/video bruger jeg det, det er fint." }
\end{aligned}
$$

De fleste studerende aktualiserer ikke mediets tilbud om tid-og-stedfleksibilitet, når tid-og-sted-dimensionen rækker ud over universitetets eller hjemmets mure.

\footnotetext{
${ }^{6}$ International forskning trækker på samme temaer. Fx Malan, (2007), Molina (2006), Johnson et al (2008) 
På spørgsmålet, hvilke procent-andele hhv. de netmedierede produkter som podcasts fylder i forhold til papirbårne tekster er svarerne mellem $0 \%$ til de netmedierede produkter og 100\% til papirtbårne tekster til 5\% til de netmediere produkter og 95\% til papirbårne tekster.

De studerendes begrundelse handler primært om effektivitet og dermed tid som en knap ressource. De får hurtigere produceret opgaver ved at fravælge de i undervisningen udbudte programprodukter. En studerende siger: "Jeg vil stole mere på en bog end på en video på nettet", en anden studerende mener at: "det er problematisk, det med at referere til en video". En tredje studerende fremfører et pragmatisk perspektiv: "Det hjælper ikke, når der er en lang tekstpensumliste, så bruger man jo ikke de andre medier, som kun er supplementer"

Nogle studerende vil gerne bruge fx auditive produktioner (ipod), når de løber eller cykler en tur, mens andre foretrækker at skille deres aktiviteter ad: "jeg vil hellere nyde løbeturen". De studerende er dog enige om, at de ikke koncentrerer sig om fx både trafik og indhold i podcasts. Flere studerende mener, at det gamle ordsprog hver ting til sin tid ganske godt indrammer, hvorfor de ikke vælger at lytte til en podcast, mens de fx er i fittnesscenter. Det forhindrer på den anden side ikke, at de lytter til musik eller "De sorte spejdere", samtidig med de fx løbetræner. De studerende skelner i den sammenhæng mellem nydelse- og nytteværdi af podcast-brug.

\section{Podcasts, kommunikation og læring}

Ideen om at viden uhindret kan transporteres fra fx underviser til studerende og på den baggrund argumenterer for effektivisering af undervisningen, har de studerende kontante meninger om:

\section{"Man er jo altid nødt til at læse teksten. Jeg tror ikke på, at den skal være før den podcast/videosekvens, der eventuelt kunne understøtte en tekst. Jeg har gået til forelæsning uden at have læst og ikke fået noget ud af det."}

Her tematiseres bl.a. betydningen af at læse tekster som forberedelse til envejskommunikation. Flere studerende ser det som en nødvendighed at have forberedt sig til en forelæsning og forberedelse betyder, at den af underviser angivne tilhørende tekst bliver læst før forelæsningen.

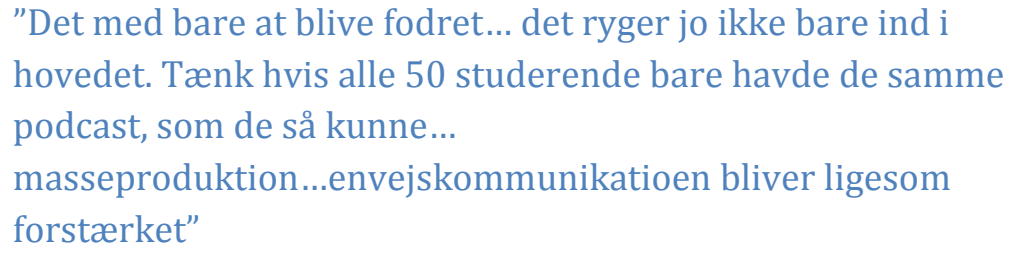


I flere sammenhænge pointerer de studerende, at podcasts kan være nyttige ressourcer, men det helt afgørende er, at underviser ikke fokuserer på mediet i sig selv, men på hvordan mediet er tænkt ind i undervisningen og dermed, hvordan det skal bruges og med hvilken vægt: "Ja det kommer an på hvordan podcast bliver brugt, det skal være pensum, ikke kun supplement".

Her skal tilføjes, at podcasts formidlede indhold, efter de studerendes mening, skal inddrages aktivt i de øvrige undervisningsaktiviteter, som fx tilstedeværelsesbaserede og netbaserede aktiviteter, hvis disse medier skal have en nytteværdi.

En studerende melder skarpt ud, hvad podcasts ikke kan, nemlig tilpasse sig den enkeltes forudsætninger for at forstå: "Selvom jeg så havde hørt podcasten 20 gange, havde jeg ikke forstået det".

Pointen er, at en podcast ikke kan variere sin kommunikation, men blot giver mulighed for at gentage kommunikationen. Det ville svare til at underviser, når en studerende spørger til sin forståelse, at underviser blot gentager ordret, hvad han/hun lige har sagt (og gør det igen og igen). Den 'reflekterede' underviser vil typisk forsøge at formulere sig på nye måder og med nye eksempler. Derfor ses podcasts i den sammenhæng ikke som et medie, der kan erstatte en underviser, der formår at tage udgangspunkt i den studerende og med en vifte af variationer, kan eksemplificere og nuancere sine formuleringer og eksempler.

Når det drejer sig om de "korte" podcasts (kategori 1 og 2) ser flere studerende et læringspotentiale i disse medier. De foreslår at undervisere stiller op til "paneldiskussioner" om fx definition af begreber og efterfølgende diskussion af disse ud fra de forskellige teoretiske perspektiver, der er bragt på banen: "Hvis to professorer kan referere til teksterne og definere begreber på forskellig måde og diskutere, hvad det betyder, kort,... det er det vi har brug for". Og dette suppleres af følgende bemærkning fra en studerende, hvor udgangspunktet er de "lange" podcasts (kategori 3) og hvor dette kobles med alternativer, hvad angår inddragelse af den sociale dimension: "Video kører bare, man kommer til at sidde og nikke lidt, mediet er ikke socialt". Med denne udmelding sættes fokus på den sociale dimension.

\section{Podcast og det sociale}

I samtlige interviews pointerer de studerende nødvendigheden af tilstedeværelsesbaseret kommunikation og at denne har forrang. 
Den kommunikative dimension, diskuteres bl.a. i følgende sekvens af et gruppeinterview:

"A: Det vil gå ud over det sociale. Det har betydning for mig. Du får ikke de samme indspark. Det er fint nok, hvis du er syg en dag. Og selvfølgelig, hvis man kun tænker på eksamen, kan det da være ok, men ikke generelt.

B: Forcen ved, at det hele er optaget, er du kan stoppe, reflektere og spole tilbage og fortsætte. Hvis man kunne lave et notesystem, der kunne understøtte det, der blev fortalt på video. Altså, dette henviser til pkt 5. i min forelæsning 4.

C: Jeg vil bruge videoerne, talking head, som noget ekstra ... men det er svært at sige, det er det, jeg umiddelbart vil mene."

En studerende udfolder temaet yderligere:

"Jeg vil helt hen på universitetet og ikke over nettet, der er altså forskel på at være MBA studerende og i arbejde er din identitet konsolideret i arbejde og familie, men vi er studerende og vores identitet er at gå til undervisning, det er da også en flad fornemmelse bare at sidde derhjemme, der er altså noget identitetsbærende ved at være på universitetet."

Det betyder meget for de fleste studerende, at de har en klar opfattelse af deres rolle som studerende - et kompleksitetsreducerende element i deres tilgang til studier, undervisning og eksamen.

"Ja, så ved man, hvad lærere vil, så har man fået et facit, men så har man også sværere ved at stille spørgsmål til facit, til fortolkningen...

Det kan gå begge veje, nu får vi en god diskussion, eller ok det var facittolkning, ok så er det det."

De fleste af de interviewede studerende søger efter "facit", i den forstand, at de gerne vil have underviser til at fortælle "den rigtige tolkning" af fx en tekst, men samtidig giver nogle studerende udtryk for, at det også kan være en befrielse at måtte stille spørgsmål og diskutere de frembragte tolkninger.

De fleste studerende pointerer i interviewene, at tilstedeværelseskommunikation er det vigtigste forum for dem som studerende. Og at stærk styring fra undervisers side er at foretrække, frem for at lade det være op til de studerende, hvad de vil arbejde med i hvilke 
fora. En studerende siger dette meget skarpt: "Jeg tror ikke på ansvar for egen læring". Podcasts i alle kategorier betragtes ikke som erstatning for undervisning, som ifølge de studerende er forelæsninger og holdundervisning, hvor underviser har forberedt sin formidling af dagens tekst og på sin vis dels fralægger de studerende den værste vægt af ansvar, dels giver de studerende mulighed for at diskutere $\mathrm{i}$ tilstedeværelsesbaserede kommunikationsfora, hvilket fremhæves som særdeles væsentlig.

\section{Podcats og undervisning}

De fleste interviewede studerende forstår begrebet undervisning som en traditionel forelæsningsorganisering, hvor underviser formidler lektien evt. med efterfølgende hjælpeformidling fra tutorer.

De studerende er stort set enige om at podcasts/videoer, specielt de lange produktioner ikke kan erstatte undervisning. Følgende nedslag fra gruppeinterview illustrerer bl.a. dette:

\section{"A: [...]Talking head er ikke undervisning, det er heller ikke undervisning at læse en bog der hjemme, jeg vil hellere se det som forberedelse til undervisning. Podcastede forelæsninger er IKKE undervisning.}

\section{B: Det er heller ikke undervisning når man har dialog med underviser og de andre studerende. Når læreren går ind og diskuterer i diverse konferencefora. Det er heller IKKE undervisning.}

C: Jeg vil kunne klare at hver anden gang var et podcasted båndet forelæsning men så skulle den anden gang ikke være mere end på 12 deltagere [...] Jeg har prøvet det, og der kunne du ikke gemme dig, du var nødt til at være aktiv, og det betød også at du fik lov at spørge. Det var ikke så svært at komme med sin holdning og sine spørgsmål til teksten og det, der blev sagt.

\section{B: Hvis man så bare fik noget belønning i form af mere intime} hold"

Nogle studerende vil strække sig så langt, som til at lade hver anden ugentlige undervisningsgang (3 lektioner) erstatte med en videooptagelse af en forelæsning. Men der skal så undervisningsorganisatorisk kompenseres for den manglende tilstedeværelsesbaserede kommunikation, ved fx at dele et hold op, så muligheden for at komme til orde med spørgsmål og kommentarer bliver større. Podcasts betragtes ikke 
som et medie, der kan erstatte kendt lærerstyret tilstedeværelsesbaseret undervisning, hvilket de fleste interviewede studerende foretrækker.

En belønning for at acceptere brug af bl.a. anvendelse af podcasts er i de studerendes optik, at de får mulighed for at opleve deltagelse af underviser på mindre hold - og hermed en større mulighed for at komme på banen og mulighed for feed-back på fx forståelseskontrollerende spørgsmål.

Når de studerende bliver spurgt, hvordan deres ønske-undervisningsforløb skal organiseres og hvilke medier, der skal i spil, nævner de fleste små hold, en styrende underviser, der stiller klare krav og rammer for tekstlæsning og afleveringer, der giver sit bud på tolkning af teksten, har markeret rolleforventninger og rollefordelinger og i øvrigt er inspirerende under forelæsningen.

Følgende lille sekvens fra gruppeinterview fortæller om de studerendes refleksioner mht. podcastmediets bidrag til det samlede undervisningstilbud på universitetet:

\section{"A: En forelæsning på video er ikke en kvalitetsforbedring i sig selv \\ B: En forelæsning er jo i en kontekst, hvilke tekster bygger den på, og hvilke tidligere tekster inddrages, man føler sig udenfor, når jeg følger en forelæsning, føler jeg mig ikke på samme måde udenfor."}

De studerende pointerer at det at have muligheden for at anvende podcast ikke i sig selv kan betragtes som kvalitetsudvikling af undervisningen. Det er mere komplekst end som så, hvilket bl.a. betyder, at såvel podcastproduktionens indholdsmæssige kontekst som anvendelseskontekst har betydning for grad af anvendelighed.

\section{Kommunikation og videnskonstruktion - et systemteoretisk blik på podcasts muligheder og begrænsninger}

I dette afsnit vil det systemteoretiske grundlag kort blive opridset, og brugt i relation til artiklens tema, og følgelig indlede en diskussion om podcasts muligheder og begrænsninger set i et kommunikations- og læringsteoretisk perspektiv. 


\subsection{System - omverden}

Udgangspunktet er systemer iagttaget som operativt lukkede, selvreferentielle, autonome og dermed selvskabende (Luhmann, 2000). Systemer iagttager deres omverden, og da systemer er operativt lukkede, betyder det, at hvert system skaber sig selv via sine systeminterne operationer. Et systems iagttagelser af sin omverden kan betragtes som næring for systemets selvskabende oprationer, eller med Luhmanns eget begreb, "perturbation"(Luhmann, 2000:180). Den studerende kan lære sig noget, og undervisningens funktion er at skabe kommunikative rammer i bredeste forstand og dermed tilbyde næring fx i form af tilbud om diverse aktive diskussionsfora, weblogs, hvor feedback på fx skriftlig opgave og indlæg er en mulighed. Podcasts, netmedierede tekster, kompendier mm vil ligeledes kunne betragtes som næring for den studerendes læreprocesser og dermed konstruktion af viden.

Den studerende vil i denne sammenhæng blive betragtet som et psykisk system, der skaber og opretholder sig selv via bevidsthedsaktiviteter og undervisning vil blive betragtet som et system, der skaber og opretholder sig selv via kommunikation (sociale systemer), jf. afsnit 4.2 og 4.3.

Da de to typer systemer opererer i hver deres modus (henholdsvis bevidsthedsaktiviteter og kommunikation), er psykiske og sociale systemer operationelt lukkede for hinanden. De er strukturelt koblede og kan påvirke hinanden (perturbationsbegrebet) til fortsatte systeminterne operationer. Det betyder, at læring, iagttaget som bevidsthedsaktiviteter, som kan resultere i konstruktion af viden, og undervisning, iagttaget som den særlig form for kommunikation, der kan give næring til systemers forandringsprocesser, opfattes som operativt lukkede for hinanden og potentielt strukturelt koblede til hinanden via fx et tema for kommunikationen. (Bl.a. Luhmann 1985, 1986, 1996, 2000, 2002).

Systemers selvskabelse og operative lukning får konsekvens for muligheden for at fremskrive simple kausalitetsrelationer, som fx ideen om transfer af viden fra underviser til de studerende. Med andre ord, der er ikke en simpel årsagssammenhæng mellem undervisning og videnskonstruktion (Mathiasen, 2007), hvilket de følgende afsnit vil udfolde.

Når systemer er strukturelt koblede, giver det et system mulighed for at tilbyde sig som omverden for et andet system. Hvad der videre sker i de system, er ikke som sådan synligt eller muligt at styre, jf. systemegenskaberne. Bevidsthedsaktiviteter, (tænken, følen, sansen) er ikke synlige for en iagttager, da tanker ikke forlader et psykisk system som tanker, men som sproglige konstruktioner. Vi har med andre ord principielt at gøre med ikke-kausale systemer (Mathiasen, 2007b). 


\subsection{Kommunikation}

Selve kommunikationsbegrebet adskiller sig fra tidligere transfermodeller (fx Shannon \& Weaver 1949/1971) ved at definere kommunikation som en syntese af tre selektioner, hvor de to selektioner - valg af information og meddelelsesform - foretages af den meddelende mens den tredje selektion valg af forståelse - foretages af adressat. Der skal således to systemer til en kommunikationsenhed. Dette kommunikationsbegreb kræver, at en adressat retter sin opmærksomhed mod meddelelsen af information og derefter vcelger forståelse. Meddeler og adressat kan inden for den teoretiske ramme forstås som "black boxes” (Luhmann 1986:9). De kan iagttage hinanden, men har ikke adgang til hinandens tanker. I nærværende sammenhæng kan meddeler og adressat tænkes som to personer (psykiske systemer), der skiftes til at være henholdsvis meddeler og adressat, alt efter hvis 'tur', det er. Fx kan underviser være den meddelende i første tur, og den studerende være adressat for meddelelsen, hvorefter rollerne byttes om og den studerende bliver den meddelende, eksempelvis med et afklarende spørgsmål adresseret til underviser (adressat). Underviser kan så i en tredje tur vælge at meddele den studerende (adressat) sit svar på den studerendes spørgsmål, hvorefter den studerende kan meddele underviser (adressat) et uddybende spørgsmål osv. Da adressats valg af forståelse (bevidsthedsaktiviteter) ikke er mulig at iagttage (black box), er det med det introducerede kommunikationsbegreb nærliggende at konkludere, at kommunikation i princippet må iagttages som usandsynlig, hvilket nødvendigvis må få konsekvenser, når spørgsmålet drejer sig om, hvilke relationer der kan tænkes at være mellem undervisning og læring (Mathiasen 2008).

De første to selektioner i en kommunikationsenhed bruger sprog som medie, hvor sprog her skal forstås i bredeste forstand (kropssprog, gestik, intonation, pausering, mimik og verbalt sprog). Den meddelte information (de to første selektioner) kan iagttages, mens den tredje selektion, valg af forståelse ikke kan iagttages (bevidsthedsaktivitet).

Først ved adressats valg af efterfølgende meddelelse kan der tilskrives en forståelsesselektion, og denne er altid systemspecifik, i den forstand at det tilskrivende systems observationer er netop dette systems optik.

Konsekvensen af denne tilgang er, at blot det at meddele noget, ikke i sig selv, er kommunikation. Adressat skal koble sig til det meddelte og selektere forståelse før en kommunikationsenhed er aktualiseret.

En podcast er i sig selv således ikke kommunikation, hvis ikke den studerende kobler sig til den meddelte information via egne selektioner af forståelse. Hvis den studerende udelukkende har denne kontekst som undervisningsmæssig ramme, vil der ud fra det introducerede kommunikationsteoretiske perspektiv kunnet argumenteres for, at denne form for undervisning kan betegnes som ganske vovelig. Hvis den studerende ikke har andre muligheder end blot at gentage den meddelte 
information medieret i podcasten, kan dette ikke betragtes som befordrende for den studerendes konstruktion af viden. Som en studerende nævner: "Selvom jeg så havde hørt podcasten 20 gange, havde jeg ikke forstået det". I en kontekst, hvor den studerende kun har podcasts som kommunikativ ramme, vil det kun være inden for denne ramme at den studerende kan kontrollere sin forståelse af det meddelte. Muligheden for at få den meddelte information formuleret på alternative måder, fx via en medstuderende eller underviser, er i denne konkrete anvendelseskontekst ikke til stede, ligesom andre muligheder for feed-back er fraværende.

Podcasts kan, ud fra den anlagte kommunikationsteoretiske optik, med fordel tænkes som en ud af flere aktualiserede kommunikationsfora. Disse fora kan på forskellig vis være rammesættende for kommunikativt at berige og udfolde de konkrete temaer fx med udgangspunkt i en podcast. Undervisning kan i sådanne sammenhænge fremstå som potentiale, når det gælder understøttelse af videnskonstruktion. Sociale systemer kan således betragtes som understøttende for psykiske systemers læring, specielt når forståelseskontrol og feed-back er en grundlæggende mulighed. Psykiske systemer kan omvendt bidrage til, perturbations-dimensionen, sociale systemers fortsatte opretholdelse, ved fortløbende at bidrage med indlæg (de to første selektioner af en kommunikationsenhed).

\subsection{Undervisning}

Kommunikation kan i denne sammenhæng siges at være et systems mulighed for og intention om at påvirke et andet system. Undervisning iagttages som den særlige form for kommunikation, der har som intention at forandre, og det betyder konkret, at undervisning iagttaget som kommunikation, har som formål at tilbyde næring og tilbyde sig som en ramme, der muliggør igangsættelse/fortsættelse af læreprocesser og dermed fortløbende videnskonstruktion.

Undervisning betragtes som et socialt system, hvor underviser og studerende deltager med kommunikative bidrag. Kommunikation, i forståelsen undervisning, er ikke kun noget, der udøves af underviser. De studerendes valg af forståelse og kommunikative bidrag er også med til at give næring til de deltagende i det sociale system, til undervisningen.

Den studerende kan lære sig noget, jf. systemkarakteristika, og underviser kan ikke via transfertænkning forvente, at de kan overføre deres viden til de studerende - i den forstand at de kan videregive de studerende, hvad de selv ved. Konsekvensen er ikke at underviser er sat ud på et sidespor eller bliver distributører af egne eller fremmedproducerede podcasts. Tværtimod er undervisere helt centrale i forhold til undervisningen, idet de skal tilrettelægge undervisningsmiljøer, der giver de bedste mulighedsbetingelser for, at de studerende kan lære sig det, der kræves ifølge de formelle krav. Det indebærer, at underviser stiller sig 
kommunikativt til rådighed, hvilket ikke kun drejer sig om fx forelæsninger (fysisk tilstedeværelsesbaserede/podcats) og vejledning. Undervisning er i den her anlagte ramme også kommunikation i fx netmedierede konferencefora og fysiske tilstedeværelsesmøder i forbindelse med gruppearbejde.

\subsection{Videnskonstruktion - et resultat af bevidsthedsaktiviteter}

Den studerende kan betragtes som et unikt system, der iagttager sin omverden med den optik og med det mentale beredskab som på det givne tidspunkt er muligt for dette system at aktualisere. Sagt med andre ord er enhver iagttagelse iagttagerafhængig og konsekvensen af denne tilgang er, at valg af forståelse er systemspecifik. Undervisning kan i princippet resultere i mindst lige så mange valg af forståelser af det af underviser meddelte, som der har været studerende til stede.

Et sådant kommunikations- og læringsteoretisk udgangspunkt har konsekvenser for måden at tænke undervisningsorganisering, herunder valg af undervisningsmedier. Traditionelle undervisningsformer som forelæsninger vil i den her anlagte teoretiske ramme ikke være en form, der kan stå alene, idet en forelæsers meddelelser ikke nødvendigvis vil blive forstået, som forelæser havde tænkt sig, og forelæsers mulighed for en efterfølgende feed-back og fortløbende gensidig forståelseskontrol er om ikke udelukket, så af begrænset omfang. Det betyder ikke, at studerende ikke kan lære sig noget ved at gå til forelæsninger (anvende podcast/forelæsning). Det betyder blot, at den videnskonstruktion, der måtte være resultatet ikke nødvendigvis er den, som forelæser har intenderet. Ideen om at en fyldt forelæsningssal eller studerende, der har anvendt forelæsnings-podcasts efterfølgende har konstrueret samme viden, er med andre ord meget lidt sandsynlig inden for den her anlagte lærings- og kommunikationsteoretiske ramme.

\subsection{Undervisning og konstruktion af viden}

Undervisning er som nævnt intentionelt funderet, og da der er tale om operativt lukkede selvstyrende systemer er dette en aktivitet, der på grund af en udelukkelse af kausalitet ikke tilbyder universelle resultater og løsninger (Luhmann 2002). Den systemteoretiske tilgang, som den er fremlagt her, giver i stedet mulighed for at betragte kommunikation som en væsentlig faktor, når valg af undervisningsorganisering og valg af arbejdsformer skal besluttes. Hvis underviser skønner, at studerendes og egen forståelseskontrol er en vigtig parameter, kunne eksempelvis gruppearbejdsformer med mulighed for fortløbende vejledning være en mulighed. Eksempelvis kunne de nævnte casebaserede podcast-kategorier indgå som undervisningsmedier i en sådan organisering af arbejdsformer. Deltagerstyrede problemorienterede projektorganiserede forløb, hvor underviser og den/de studerende i mindre fora kan diskutere udvalgte 
faglige temaer kunne ligeledes være en undervisningsorganisering, hvor kommunikationen har andre mulighedsbetingelser end eksempelvis undervisning på større hold.

Der er dog ikke nogen garanti indbygget i de forskellige undervisnings- og arbejdsformer. Selv nok så megen kommunikation om et fagligt tema garanterer ikke, at alle har valgt forståelse, som intenderet af underviser. Kommunikation kan dog eksempelvis give underviser mulighed for at korrigere en forståelse, som er meddelt af en studerende. Ligeledes vil forskellige konfigurationer af samarbejde mellem studerende give mulighed for kommunikation om faglige temaer og dermed kunne påvirke den enkelte studerendes valg af forståelse.

\section{Hvad er podcasts svaret på?}

Uanset hvilke af de i casen beskrevne podcast-kategorier, der fokuseres på, er der, i den anlagte teoretiske ramme, først tale om en kommunikationsenhed, (syntesen af tre selektioner, de to første knyttet til meddeler og den sidste knyttet til adressat), når fx den studerende (adressat) har rettet sin opmærksomhed mod fx en podcast og valgt forståelse. Denne kommunikationsenhed, denne "ene tur", hvor meddeler vælger information og meddelelsesform og adressat selekterer forståelse kan i princippet kaldes undervisning, fordi undervisning her er beskrevet som den særlige kommunikation, der intenderer forandring, hvilket ikke kan udelukkes hænder, når fx en studerende følger med i en podcastet videoforelæsning. Spørgsmålet er imidlertid, hvilke forandringer i den studerendes vidensstrukturer, der er aktualiseret. Med andre ord, hvilken viden, den studerende har fået konstrueret og om disse konstruktioner ækvivalerer intentionerne med undervisningen (kommunikationen). Dette vil fx kræve, at der etableres et kommunikationsforum, hvor underviser og studerende har mulighed for gensidigt at udøve forståelseskontrol og dermed bl.a. give den studerende mulighed for vise, at den nye viden kan bidrage til, at han/hun kan agere på nye måder og dermed har mulighed for at kunne tilegne sig anden/ny viden på baggrund af sin nykonstruerede viden.

Undervisning som "en-vejs"-kommunikation må betragtes som risikabel, i den forstand, at præmisserne for adressat er at han/hun skal kunne følge med og opretholde opmærksomheden i den sekventielle form for meddelelse af information uden at kunne udøve fortløbende forståelseskontrol med andre end podcastmediet, og dermed har adressat ikke mulighed for at korrigere sin selektion af forståelse udover udbredelsesmediets præmisser. Som modargument kan nævnes, at den studerende har mulighed for at "spole frem og tilbage" i den videostreamede forelæsning i det uendelige, lige såvel som kommunikationstempo kan "sættes op og ned", hvilket giver mulighed for http://forskningsnettet.dk/lom 
individuel brug af en podcast. Hertil kan der ud fra den introducerede kommunikations- og læringsteoretiske optik nævnes, at kommunikation, ved blot at blive gentaget ordret i den uendelige, ikke har en større sandsynlighed for at resultere i den intenderede vidensskonstruktion hos adressat. Resultatet kan blive, at adressat kan gengive den meddelte information ordret, hvilket kan være målet med brug at fx en podcast, og så kan

medievalg, anvendelseskontekst og mål siges at hænge sammen og understøtte hinanden.

Er målet $\mathrm{fx}$ at adressat skal kunne eksplicitere valg af forståelse og måske kunne bruge sin nye viden i diskussioner med medstuderende, kræver brugen af podcast en konkret anvendelseskontekst, der understøtter aktualiseringen af de studerende videnskonstruktioner. Med andre ord kræver det at organisering af undervisning giver den studerende mulighed for at kunne udøve forståelseskontrol og dermed mulighed for at få løbende feedback.

Hvis podcast-mediet skal tilskrives et anvendelsesperspektiv, der fokuserer på et læringsunderstøttende potentiale, er den konkrete brug af mediet væsentlig at tage udgangspunkt i. Det gælder alle tre kategorier, som er aktualiseret i casen.

Podcasts er i den forstand ikke noget i sig selv. Først når en podcast tages i brug af studerende og underviser, kan mediet aktualisere intenderede kommunikation- og læreprocesser. Det betyder, at brug af en podcasts indhold skal tematiseres i kommunikationen og dermed inddrages i oplæg/diskussion/gruppearbejde osv., hvilket kan ske i såvel en netmedieret som tilstedeværelsesbaseret undervisningsorganisering. Sker denne aktualisering af den podcastede information ikke, fravælger de studerende dette udbredelsesmedie. De studerendes valg/fravalg af medier kan tilskrives en tids-, sags- og socialdimension (Luhmann, 2000:116).

Tiden opfattes af de fleste studerende som en knap ressource, og denne skal ydermere deles mellem mange forskellige aktiviteter, studierelaterede som ikke studierelaterede. De studerende giver udtryk for at deres valg af konkrete medier og netmedierede kommunikationsfora, angivet af underviser, afhænger af en forventet effekt. Den overvejende tendens er, at de studerende vælger de medier, der opfattes som den letteste vej til opfyldelse af studiets ekspliciterede eksamensfordringer. Denne tilgang til studiet betyder følgelig, at mange studerende giver udtryk for, at ville ledes af underviser, overlade styring og organisering til underviser og dermed ikke bruge tid på studiet, som ikke fører til muligheden for at honorerer eksamenskrav. I den præsenterede case er de studerende på overbygningsuddannelsen, og for fleres vedkommende mangler de kun specialet. De studerende har således ganske mange års erfaring som 
universitetsstuderende, men giver stadig udtryk for ønsket om faste rammer og at få dikteret, hvad der skal læses til hvornår. Ingen af de studerende har haft behov for at spørge: hvorfor - i stedet ønsker de en klar udmelding om forventninger til dem fra undervisers side, så de kan levere det, der skal til, så godt som muligt inden for en egenprioriteret tidsramme.

I denne sammenhæng vil sagsdimensionen have fokus på podcasts tematiske indhold, (information og meddelelsesform) og de studerendes valg/fravalg af disse. De i casen præsenterede podcast-kategorier, har fået forskellige vurderinger af de studerende. De fleste studerende vil fravælge podcastede forelæsningsvideoer, fordi de ikke mener, at indholdet får lov at udfolde sig pga. organiseringen af indhold og form. Der er forslag om at produktudvikle podcasts i form af videoforelæsninger, fx ved at skærmen inddeles, så "the talking head" ikke fylder hele skærmbilledet, men at der gives plads til evt. diasshow, whiteboard/smartboard, skriftlig dialog (synkron/asynkron) og markører, der gør det let at navigere i podcastproduktionen.

Bruges denne type udbredelsesmedie i en synkront organiseret undervisningskontekst, foreslår de studerende, at der er mulighed for skriftligt løbende at kunne stille spørgsmål. Endvidere ser de det som en fordel, hvis der er mulighed for at stille mundtlige spørgsmål og få realtime-feed-back. Hvis denne type af video skal fremstå som attraktivt for de studerende, skal der være en form for referencesystem, som gør, at de studerende med ligeså stor lethed og legitimitet, som når de bruger skriftlige medier, kan referere til konkrete sekvenser i en video.

Mange studerende mener ikke, at podcastede forelæsningsvideoer kan betragtes som undervisning. Nogle sidestiller det med en bog. Tilgangen her er, at disse udbredelsesmedier kan fungere som forberedelsesmedier til undervisningen, hvilket de fleste studerendes iagttager som den kendte form for undervisningsorganisering, hvor underviser gennemfører sin forberedte forelæsning. Nogle studerende mener ikke, at dialog med underviser fx i netmedierede kommunikationsfora eller undervisers deltagelse i en gruppediskussion kan betegnes som undervisning. I disse konkrete eksempler harmonerer de studerende tilgang ikke med det anlagte undervisningsbegreb, idet netop kommunikationens fortsættelse og dermed mulighed for fortløbende forståelseskontrol i den undervisningsmæssige ramme giver mulighed for, at intenderede forandringer aktualiseres. Denne tilgang præsenterer underviser (jf. interviewcitater). Underviser og de studerende (de fleste) har ikke samme tilgang og forventninger til begrebet undervisning. Og dermed heller ikke til vejen ad hvilken, de fordrede uddannelseskrav gives de bedst mulige udviklingsbetingelser. 
De to øvrige podcasts-kategorier, som er brugt i casen, anser de studerende for mere integrerbare i undervisningen og nyttige som små appetizers eller direkte anvendelige instruktionsvideoer i konkrete anvendelseskontekster. Fx foreslås, korte podcasts ( $5 \mathrm{~min}$ ), hvor underviser evt. med kolleger introducerer et eller flere begreber og kort diskuterer indhold og konsekvenser af brugen af disse begreber. En sådan type af podcast ser de et potentiale i, og en mere relevant udnyttelse af netop muligheden for at anvende programs-on-demand, idet de studerende mener, at sådanne podcast vil kunne aktualiseres i bussen eller andre steder, hvor tiden kan udnyttes til et kort fagligt indspark. Her ses envejskommunikationen som et alternativ til forberedelsesaktiviteter og samtidig en mulighed for at give mere plads til underviser i forbindelse med tilstedeværelsesbaseret undervisning.

Den sociale dimension, i form af en rammesætning, der organiserer undervisningen som fysisk tilstedeværelsesbaseret, er afgørende for de fleste af de studerende. De pointerer, at de har brug for at spejle sig i hinanden. Det handler om det studierelaterede og faglige. Flere studerende argumenter for fysisk tilstedeværelsesbaseret undervisningsorganisering frem for netmedierede kommunikation på baggrund af deres iagttagelse af sig selv som en studerende, der "går til undervisning". De studerende mener, at hvis de ser en podcastet videoforelæsning sammen og anvender de to $\emptyset$ vrige podcast-kategorier, de er blevet introduceret til i undervisningsforløbet i konkrete anvendelseskontekster, vil deres medløbende kommunikation med medstuderende, være en måde at bruge disse medier på, der kan være understøttende for deres konstruktion af viden og samtidig være understøttende for samarbejde, fælles begrebsudvikling og faglige progression. De studerende er således opmærksomme på at forskellige kommunikationsfora kan facilitere forskellige behov og at tid-og-sted-dimensionen har indflydelse på i hvilken grad den i udgangspunktet usandsynlige kommunikation kan fremstå som mere sandsynlig.

Der har i denne artikel været sat specielt fokus på podcast-mediet og brugen af forskellige kategorier af podcasts. Casen kan betragtes som en invitation til fortsatte pædagogiske refleksioner over design af podcasts og den konkrete anvendelse af podcasts i undervisningen. Endvidere kan casen set i den systemteoretiske optik, bruges som øjenåbner, når det gælder de studerendes implicitte antagelser og konkrete tilgang til undervisning og mediebrug $\mathrm{i}$ bredeste betydning.

Hermed inviteres til diskussion af podcast-design og podcast-brug i undervisning, fx med udgangspunkt i følgende temaer:

- Produktudvikling af programmes-on-demand: til hvem, hvornår, om hvad, og hvor lange? 
- Podcast som kommunikations- og læringsunderstøttende medie: hvilke kontekster og hvilke temaer?

- Podcast som undervisning: Hvornår, hvordan og hvorfor?

\section{Litteraturliste}

Cuban, L. (1986): Theachers and Machines. The classroom of technologgy since 1920. New York: Teacher College Press

Dalsgaard, C.og H. Mathiasen (2006), "Konferencesystemers potentialer i forhold til projektarbejde", i Mathiasen, H. (red.) Læring og it, Aarhus Universitetsforlag, Århus

Johnson, L et al (2008): Pod-casting and VOD-casting as Reusable Learning Objects, paper AERA.-presentation

Luhmann, N. (1985): Complexity and Meaning, in The Science and Praxis of Complexity, Japan: The United Nations University

Luhmann N. (1986): Systeme Verstehen Systeme, i Luhmann og Schoor (red.) Zwischen Intransparanz und Verstehen - fragen an die Pädagogik, Frankfurt am Main: Suhrkamp Verlag

Luhmann, N. (1988): Erkenntnis als konstruktion. Berlin: Bentli Verlag

Luhmann, N. (1992): What is Communication i Forum, Communication Theory, 2:3, p. 251-258

Luhmann, N. (1996): Zwischen System und Umvelt. Fragen an die pädagogik. Frankfurt am Main: Suhrkamp Verlag

Luhmann, N. (2000): Sociale systemer. Kbh. Reitzels forlag

Luhmann, N. (2002): Das Erziehungssystem der Gesellschaft. Frankfurt: Suhrkamp

Luhmann, N. (2006): Samfundets uddannelsessystem. Kbh : H. Reitzels Forlag

Malan, DJ. (2007): Podcasting computer science E-1 in Proceedings of 38th SIGCSE Thechnical Symposium on Computer Science Education

Molina, PG. (2006): Pioneering New Territory and Technologies. EDUCAUSE, Review, Vol.41 No. 5.

Mathiasen, H. (2002): Personlige bærbare computere i undervisningen, København: Danmarks Pædagogiske Universitets forlag 
Mathiasen, H. 2004, Expectations of Technology: When the Intensive Application of IT in Teaching Becomes a Possibility, Journal of Research on Technology in Education, vol. 36 nr. 3, s. 273-295.

Mathiasen, H., Dalsgaard, C. (2006): Students' use of social software in selforganized learning environment, presented in Informal Learning and Digital Media: Constructions, Contexts and Consequences, Odense, September 21-23, 2006.

Mathiasen, H., C. Dalsgaard (2007): Self-organized Learning Environments, in EISTA '07 Proceedings, International Institute of Informatics and Systemics, s. 290-294.

Mathiasen, H. (2007): Teaching and Learning in a Variety of Communication forums, in iPED Conference 2007, Coventry University Technocenter, UK, Coventry University Technocenter, UK,

Mathiasen, H. (2007): "Hvordan sikrer man sig, at de studerende lærer det, de skal?" i Qvortrup, L. et al (red) Luhmann og dannelse. Kbh: Forlaget UP

Mathiasen, H. (2008): Is There a Nexus Between Learning and Teaching? :Communication as a Facilitator of Students' Knowledge Construction in Holtham, C. et al (ed) Understanding Learning-Centred Higher Education. Kbh.: CBS Press

Shannon, E.C. og W. Weaver (1949/1971): The mathematical Theory of Communication. Urbana, Chicago, London: University of Illinois Press

Stenalt, M. Hvid og D. Sidelmann Jørgensen: Using E-tivities, Video Dialogues and Informal Communication to Motivate University Teachers Online. In proceeding of the 13th International Conference of European University Information Systems, Grenoble Universities, France. EUNIS 2007 